\title{
Relatedness and Population Differentiation in a Colonial Butterfly, Eucheira socialis (Lepidoptera: Pieridae)
}

\author{
ADAM H. PORTER, ${ }^{1}$ HANSJÜRG GEIGER, ${ }^{2}$ DESSIE L. A. UNDERWOOD, ${ }^{3}$ \\ JORGE LLORENTE-BOUSQUETS,${ }^{4}$ AND ARTHUR M. SHAPIRO ${ }^{3}$
}

\begin{abstract}
Ann. Entomol. Soc. Am. 90(2): 230-236 (1997)
ABSTRACT Eucheira socialis (Westwood) occurs above $1,800 \mathrm{~m}$ in mountains throughout Mexico and has a remarkable suite of autapomorphies, including communal larval nests and a mean primary sex ratio of $70 \%$ males. We gathered allozyme data for 31 loci from individuals within nests within populations and used hierarchical $F$ statistics to assess population structure and relatedness at these levels. Allozyme variation was far lower than reported in most Lepidoptera, and was absent from the populations sampled from southern Mexico. Among 5 sample sites distributed throughout Mexico, differentiation was high $\left(F_{\mathrm{ST}}=0.54\right)$, which is consistent with a history of interrupted gene flow. At lower hierarchical levels in the variable populations, we found significant excess heterozygotes within nests $\left(F_{\mathrm{IN}}=-0.15\right)$ and evidence for structuring within subpopulations $\left(F_{\mathrm{IS}}=0.015\right.$, significantly greater than $\left.F_{\mathrm{IN}}\right)$. Average relatedness among nestmates was $r_{\mathrm{NS}}=0.28$, which is significantly less than $r=0.5$. This is probably caused largely by interchange among nests on multinest trees.
\end{abstract}

KEY WORDS hierarchical genetic structure, relatedness, Wright $F$ statistics, larval nest

KNOWN LOCALLY AS the mariposa del madroño or tzauhquiocuilin (Hoffmann, 1911), Eucheira socialis (Westwood, 1834) has been considered an oddity by lepidopterists since its larval nests were first described by von Humboldt (1811, p. 454). Populations are found only above $1,800 \mathrm{~m}$ in the mountains of Mexico, and detailed accounts of its natural history have been published only recently (Díaz Batres and Boudinot 1986, Kevan and Bye 1991, Underwood 1994). Females appear to mate only once, and they lay most of their eggs in single clutches of 50-400 (Underwood 1994) on the undersides of leaves of madrone trees, especially Arbutus xalapensis H.B.K. (Ericaceae). Upon hatching, the larvae of each clutch construct a communal silken nest on the leaf, and this is expanded in the 4th stadium to enclose the end of the twig in an opaque silken bag of papery texture, from which larvae emerge processionally at night to feed. They pupate inside the nest, hanging vertically by the cremaster. All other pierids attach themselves by an additional silken girdle. Up to $20 \%$ of the emerging adults show deformities as a result of expanding their wings inside the nest

\footnotetext{
'Department of Biological Sciences, Bowling Green State University, Bowling Green, $\mathrm{OH}$ 43403-0212. E-mail: aporter@opie.bgsu.edu

${ }^{2} Z$ Zoologisches Institut, Universität Bern, Baltzerstrasse 3, CH3012 Bem, Sivitzerland.

${ }^{3}$ Section of Evolution and Ecology, University of California, Davis, CA 95616.

${ }^{4}$ Museo de Zoología, Facultad de Ciencias, UNAM, Apdo. Postal 70-399, 04510 México, D.F., México.
}

(Díaz Batres and Boudinot 1986), and these adults are not likely to reproduce. The adults are weak fliers with grossly simplified sexual behaviors, and mating takes place in the vicinity of the nests (Underwood 1992); nests are not reused by later generations. The proboscis is nonfunctional and often fails to anneal properly. Adults are sexually dimorphic: females have reduced compound eyes and slightly reduced wing venation; males fly somewhat better and have exceptionally large eyes. Any of these traits is unusual for butterflies, and they are especially remarkable in combination.

Eucheira socialis nests have male-biased primary sex ratios (D.L.A.U., unpublished data), with males comprising on average $70 \%$ of the larvae in clutches. Preliminary studies suggest a partial division of labor in the construction of the nest and the maintenance of silken trails. On a per-individual basis, males do most of this work (D.L.A.U., unpublished data). Furthermore, a significant proportion of penultimate instars stop feeding, decline, and die once the nest is fully constructed, and these larvae are almost always males (D.L.A.U., unpublished data). This results in an adult sex ratio of $56-65 \%$ males, still significantly greater than 1:1 (Kevan and Bye 1991; D.L.A.U., unpublished data). In other taxa, limited "altruism" of this sort is often associated with high levels of relatedness (Hamilton 1967, Frank 1987, Thornhill 1993), and high relatedness is likely, given the natural history of $E$. socialis. 


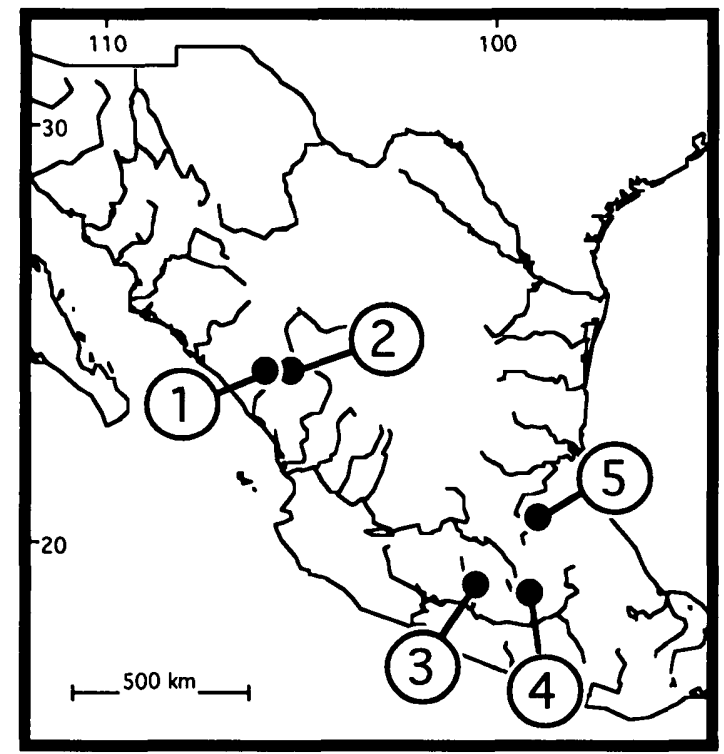

Fig. 1. Sample populations of E. socialis in Mexico. (1) El Palmito, Sinaloa; (2) El Madroño, Durango; (3) Valle de Bravo, México; (4) Pedregal de Chichinautzin, Morelos; (5) Palillos, Zimapán, Hidalgo.

In this article, we use allozyme data to look for patterns of genetic structure in E. socialis populations. In particular, we investigate the degree of geographic differentiation among populations throughout Mexico and, within populations, the degree of relatedness within larval nests.

\section{Materials and Methods}

Larval nests of $2 E$. socialis subspecies were sampled from populations in the following localities in Mexico: E. socialis westwoodi Beutelspacher, $10 \mathrm{~km} \mathrm{~W}$ El Palmito, Sinaloa (near the Durango border) (6 nests); El Madroño, Durango (29 nests); and E. socialis socialis, Cerro de Bravo, near Valle de Bravo, Mexico state (4 nests); Pedregal de Chichinautzin, Morelos (3 nests); and Palillos, Zimapán, Hidalgo (3 nests) (Figure 1). Nests with pentultimate and ultimate instar larvae were taken from trees, kept with madrone (Arbutus xalapensis) foliage in individual bags, and hand-carried to the laboratory in Davis, CA. They were reared to maturity on Arbutus menziesii Pursh., the native Californian species, and, upon emergence, samples of adults were frozen and stored at $-80^{\circ} \mathrm{C}$. Samples from reared nests were transported on dry ice to Bern, Switzerland, for electrophoretic analysis; some nests with pupae were sent directly from Mexico City to Bern; and the remainder were analyzed in Davis. Voucher material is deposited in the Bohart Museum at the University of California, Davis.

The following enzyme systems yielded a total of 31 scorable loci: Aat-1, -2 (EC 2.6.1.1), Acp (EC 3.1.3.2), Ak-1, $-2,-3$ (EC 2.7.4.7), Ald (EC
4.1.2.13), Arg (EC 2.7.3.3), Est (EC 3.1.1.1), Fum $-1,-2$ (EC 4.2.1.2), Gapd (EC 1.2.1.12), $\alpha$-Gpd (EC 1.1.1.8), Gpd (EC 1.1.1.49), Gpi (EC 5.3.1.9), $H k-1, \quad-2, \quad-3$ (EC 2.7.1.1), Idh-1, -2 (EC 1.1.1.42), Mdh-1, -2 (EC 1.1.1.37), $M e-1,-2$ (EC 1.1.1.40), Pep (EC 3.4.11.-), 6-Pgd (EC 1.1.1.43), Pgm (EC 2.7.5.1), Pk (EC 2.7.1.40), and Sod-1, $-2,-3$ (EC 1.15.1.1). Electromorphs were scored for mobility relative to standard alleles from Pieris brassicae, a method chosen for consistency with other studies of electrophoretic variability in the family Pieridae (Geiger 1981; Geiger and Scholl 1985; Geiger and Shapiro 1986, 1992; Porter and Geiger 1995).

We used hierarchical $F$ statistics (Wright 1978, Weir and Cockerham 1984) to describe allozyme variation. $F$ statistics summarize the extent to which populations deviate from Hardy-Weinberg genotypic proportions. Populations in HardyWeinberg equilibrium proportions have $F=0$. Populations with excesses of homozygotes have $F$ $>0$ to a maximum of $F=1$; those with heterozygote excesses have $F<0$ to a minimum of $F=$ -1. A population may be hierarchically organized as a group of subpopulations, whereupon $F$ in the total population, denoted $F_{\mathrm{IT}}$, may be hierarchically partitioned to describe deviations from Hardy-Weinberg expectations on different geographic scales. The partitioning is $\left(1-F_{\text {IT }}\right)=\left(1-F_{\text {IS }}\right)$ ( $1-$ $F_{\mathrm{ST}}$ ) (Wright 1951, 1978), where $F_{\text {IS }}$ describes the average of deviations from Hardy-Weinberg proportions within the subpopulations, and $F_{\text {ST }}$ describes the component of overall deviation produced by gene frequency differences among subpopulations. Other hierarchical levels are often inserted as we describe below. On local scales, within subpopulations, deviations from HardyWeinberg expectations arise from nonrandom mating, and $F_{\text {IS }}$ may be positive or negative. At larger scales, only positive values (aside from sampling variation) may arise in $F_{\mathrm{ST}}$, when the subpopulations have different allele frequencies. This Wahlund effect is easiest to imagine in the extreme case where subpopulations are fixed for different alleles, yielding a complete deficiency of heterozygotes in the total population. As such, $F_{\mathrm{ST}}$ is a common statistic describing average differentiation among subpopulations.

Historically, $F$ statistics have been derived from 3 perspectives: as the degree to which alleles identical-by-descent are distributed within and among individuals ( $f$ of Malécot 1969) and populations ( $G$ of Nei 1973); by path analysis as correlations between alleles in uniting gametes (i.e., within individuals) within and among subpopulations ( $F$ of Wright 1951, 1978); and from a nested analysis of variance model describing the pattern in which total allelic variation is partitioned among subpopulations, among individuals within subpopulations, and between pairs of alleles within (diploid) individuals (Cockerham 1969, 1973; Weir and Cockerham 1984). Although the derivations yield the 
same analytical result and their various interpretations are biologically equivalent, the $3 \mathrm{rd}$ approach lends itself most readily to statistical treatment of data because degrees of freedom can easily be incorporated at several sampling levels (Weir and Cockerham 1984, Weir 1990).

Because of the hierarchical structure of $F$ statistics, additional levels may readily be included in analyses, representing, for example, subdivisions of large subpopulations into demes (Wright 1978) or grouping of subpopulations into intraspecific geographical or taxonomic units (Porter 1990, Chesser et al. 1993). In this study we investigate differentiation at 3 hierarchical levels: among subpopulations $\left(F_{S T}\right)$, among larval nests within subpopulations $\left(F_{\mathrm{NS}}\right)$, and among individuals within nests within subpopulations $\left(F_{I N}\right)$. The partitioning is thus $\left(1-F_{\mathrm{IT}}\right)=\left(1-F_{\mathrm{IN}}\right)\left(1-F_{\mathrm{NS}}\right)\left(1-F_{\mathrm{ST}}\right)$. These hierarchical levels may be collapsed to yield $\left(1-F_{\text {IT }}\right)$ $=\left(\mathbf{1}-\boldsymbol{F}_{\mathrm{IN}}\right)\left(\mathbf{1}-\boldsymbol{F}_{\mathrm{NT}}\right)$ and $\left(\mathbf{1}-\boldsymbol{F}_{\mathrm{IT}}\right)=\left(\mathbf{1}-\boldsymbol{F}_{\mathrm{IS}}\right)\left(\mathbf{I}-\boldsymbol{F}_{\mathrm{ST}}\right)$ as above, and we also draw inferences from $F_{\text {IS }}$. We used Weir and Cockerham's (1984) statistical estimators for $F$ statistics, derived from the unbiased hierarchical variance components $a, b_{1}, b_{2}$, and $c$, as defined in their article. These estimators are

$$
\begin{aligned}
& F_{\mathrm{IN}}=1-\frac{c}{b_{1}+c}, \\
& F_{\mathrm{IS}}=\hat{f}=1-\frac{c}{b_{1}+b_{2}+c}, \\
& F_{\mathrm{IT}}=\hat{F}=1-\frac{c}{a+b_{1}+b_{2}+c}, \\
& F_{\mathrm{NS}}=1-\frac{b_{1}+c}{b_{1}+b_{2}+c}, \\
& F_{\mathrm{NT}}=\hat{\theta}_{1}=1-\frac{a+b_{2}}{a+b_{1}+b_{2}+c}, \\
& F_{\mathrm{ST}}=\hat{\theta}_{2}=1-\frac{a}{a+b_{1}+b_{2}+c},
\end{aligned}
$$

where $\hat{\theta}_{1}, \hat{\theta}_{2}, \hat{f}$, and $\hat{F}$ follows their notation. Single-locus estimates were combined over loci and alleles using a weighted average, and error estimates were obtained by the "jackknife" resampling method (Weir and Cockerham 1984).

Behavioral observations indicate that $E$. socialis nests are primarily family groups when eggs' are laid (Underwood 1992). A deviation from the appearance of "Hardy-Weinberg" proportions among larvae within nests $\left(F_{\text {IN }}\right)$ in this study is thus a measure of the deviation from Mendelian ratios within putative family groups. $F_{\text {IN }}$ would be expected to increase with 3 factors that lead to homozygote excesses: multiple paternity, coalescence of nests on the same trees, and the extent of multifemale clutches. As described below, relatedness $(r)$ is the more appropriate statistic for interpreting this level of differentiation. Differentiation among individuals within subpopulations $\left(F_{\text {IS }}\right)$ will not be influenced by these 3 factors, but may be influenced instead by nonrandom mating in the subpopulation. Given the natural history of $E$. socialis (Kevan and Bye 1991, Underwood 1992, 1994), the appearance of nonrandom mating seems more likely to arise statistically, from an inadvertent pooling of local genetic neighborhoods within the sampled subpopulations, rather than sexually, from actual mate-choice behaviors influencing consanguineous mating.

It is possible to estimate the rate of gene exchange among subpopulations using $M \approx\left(1 / F_{\mathrm{ST}}-\right.$ 1)/4 (Slatkin 1987, Cockerham and Weir 1993), where $M$ is the effective number of individuals exchanged among subpopulations per generation. For neutral loci, differentiation among subpopulations $\left(F_{\mathrm{ST}}\right)$ is produced by genetic drift and is counteracted by gene flow. Balancing selection on allozymes probably plays a negligible role in subpopulation differentiation unless the subpopulations are quite large (Porter 1990, Porter and Geiger 1995). The estimation of gene flow requires that drift and gene flow be near equilibrium. If they are not, the direction of the bias depends on whether contact among subpopulations is of primary or secondary origin. When they are out of equilibrium because of the interruption of gene flow, gene flow $(M)$ will be overestimated, and this is especially so in large populations or over geographic regions, because genetic drift will act more slowly therein (Porter and Geiger 1995).

Relatedness statistics are comparative in nature, and apply to populations of grouped individuals rather than to particular groups taken separately (Hamilton 1964, Grafen 1985). The relatedness statistic $r$ is defined as the degree to which individuals within groups deviate from the average genotype of their group, as compared with their deviation from the average genotype of the population (Hamilton 1971, Grafen 1985, Queller and Goodnight 1989). The groups may be arbitrarily chosen and, in this study, groups are nests. Like $F$ statistics, relatedness statistics may be partitioned hierarchically (Pamilo 1984). When doing so, the subscript notation is not exactly like that of $F$ statistics. The average relatedness of nestmates (individuals within nests) within subpopulations is $r_{\mathrm{NS}}$, whereas the inbreeding coefficient at this level is $F_{\mathrm{IN}}$.

We estimated relatedness among nestmates using Hamilton's (1971, appendix II) formula

$$
r_{\mathrm{NT}}=\frac{2 F_{\mathrm{NT}}}{1+F_{\mathrm{IT}}} .
$$

This is difficult to interpret when subpopulations differ in allele frequency because it compares differences among nestmates to differences from the average allele frequency of the total population. So in addition, following Pamilo (1984, equation 16), 
Table 1. Nests per site $(N)$, mean \pm SD per nest sample sizes $(\bar{n})$ and allele frequencies in each $E$. socialis subpopulation for the polymorphic loci

\begin{tabular}{|c|c|c|c|c|c|}
\hline $\begin{array}{l}\text { Locus and } \\
\text { allele }\end{array}$ & El Palmito & El Madroño & Cerro de Bravo & Chichinautzin & Palillos \\
\hline$N$ & 6 & 29 & 4 & 3 & 3 \\
\hline$\ddot{n}$ & $11.8(3-34)$ & $11.5(2-35)$ & $5.0(2-10)$ & $14.0(4-25)$ & $8.3(5-12)$ \\
\hline \multicolumn{6}{|c|}{$1-1.0(7-20)$} \\
\hline A & $0.986 \pm 0.028$ & $0.914 \pm 0.157$ & $1.00 \pm 0.00$ & $1.00 \pm 0.00$ & $1.00 \pm 0.00$ \\
\hline B & $0.014 \pm 0.028$ & $0.084 \pm 0.154$ & & & \\
\hline C & & $0.001 \pm 0.003$ & & & \\
\hline \multicolumn{6}{|l|}{$I d h-1$} \\
\hline A & $0.077 \pm 0.143$ & $0.012 \pm 0.023$ & & & \\
\hline $\begin{array}{c}\mathrm{B} \\
\mid d / h-2\end{array}$ & $0.923 \pm 0.143$ & $0.988 \pm 0.023$ & $1.00 \pm 0.00$ & $1.00 \pm 0.00$ & $1.00 \pm 0.00$ \\
\hline A & $0.775 \pm 0.349$ & $0.224 \pm 0.347$ & & & \\
\hline B & & $0.010 \pm 0.020$ & $1.00 \pm 0.00$ & $1.00 \pm 0.00$ & $1.00 \pm 0.00$ \\
\hline \multirow{2}{*}{\multicolumn{6}{|c|}{$0.220-0.049$}} \\
\hline & & & & & \\
\hline A & $0.148 \pm 0.252$ & $0.012 \pm 0.023$ & & & \\
\hline B & $0.711 \pm 0.411$ & $0.847 \pm 0.259$ & $1.00 \pm 0.00$ & & $1.00 \pm 0.00$ \\
\hline $\mathrm{C}$ & & & & $1.00 \pm 0.00$ & \\
\hline D & $0.141 \pm 0.242$ & $0.141 \pm 0.242$ & & & \\
\hline
\end{tabular}

Ranges of nest sample sizes are given in parentheses.

average relatedness among nests within subpopulations was estimated using

$$
r_{\mathrm{NS}}=\frac{2 F_{\mathrm{NS}}}{1+F_{\mathrm{IS}}} \text {. }
$$

These estimates of $r_{\mathrm{NS}}$ and $r_{\mathrm{NT}}$ are statistically unbiased, to the extent that the ratio of 2 unbiased estimators is unbiased, because they are ratios of the unbiased $F$ statistics we calculated above. We jackknifed over nests to estimate error of $r$ because there were considerably more nests than polymorphic loci. Queller and Goodnight (1989, equation 11) suggested a similar (Pamilo 1989) formula that appears generally less biased for small samples. We did not adopt it because it produces unrealistic estimates if both the number of subpopulations analyzed is very small and their allele frequencies are very different, as occurred in our sampling regime. Only the 2 northern Mexico populations were suitable for our within-population relatedness estimates because the other populations lacked genetic variation, leading to undefined estimates of $r$ in them.

\section{Results}

Genetic Differentiation. Only the loci Aat-1, Est, Gpi, and Idh-1 showed allozyme polymor- phism within or among populations (Table 1), and these were only polymorphic in the $2 E$. $s$. westwoodii populations. This resulted in heteroyzgosities of $H=0.03$ and $H=0.04$ in these populations. Heterozygotes occurred in both sexes, indicating that these loci are autosomal. The 3 populations from southern Mexico, currently placed taxonomically as $E$. socialis socialis, were homozygous at the 31 loci sampled, with heterozygosities of $H=0.0$. This is the lowest overall level of polymorphism $(\% P=13 \%)$ yet recorded for any butterfly species. These heterozygosity statistics should be interpreted with caution, however, because our methods were not designed to randomly sample individuals within subpopulations.

Hierarchical inbreeding coefficients considering all subpopulations are shown in Table 2. $F_{\mathrm{ST}}$ is quite high $(P<0.001)$, indicating virtually complete isolation of subpopulations. If this is converted to a gene flow estimate, then $M \approx 0.21$ (0.11-0.40, 95\% CI) individuals exchanged among subpopulations per generation. This is just above the range of values seen when genetically isolated, sympatric sibling species are compared, and somewhat lower than most cases of subspecific differentiation (Porter 1990). The lack of genetic diversity in the E. s. socialis subpopulations makes further interpretation of genetic structure prob-

Table 2. Hierarchical $\boldsymbol{F}$ statistics for all $\boldsymbol{E}$. socialis subpopulations, using the formulae of Weir and Cockerham (1984) (see Materials and Methods)

\begin{tabular}{|c|c|c|c|}
\hline F statistic & Level & Value & SD \\
\hline$F_{\mathrm{ST}}$ & Among subpopulations & 0.543 & 0.081 \\
\hline$F_{\mathrm{NT}}$ & Among nests & 0.613 & 0.072 \\
\hline$F_{\mathrm{IT}}$ & Among individuals & 0.555 & 0.094 \\
\hline$F_{\mathrm{NS}}$ & Among nests within subpopulations & 0.152 & 0.006 \\
\hline$F_{\text {IS }}$ & Among individuals within subpopulations & 0.026 & 0.031 \\
\hline$F_{\text {IN }}$ & Among individuals within nests within subpopulations & -0.148 & 0.029 \\
\hline
\end{tabular}

Standard deviations are derived from jackknifing over loci. 
Table 3. F statistics considering only the $E$. s. westwoodi subpopulations from northern Mexico, where sufficient variance in allele frequency exists to permit more detailed analysis

\begin{tabular}{clrrrr}
\hline \hline \begin{tabular}{c}
\multicolumn{1}{c}{ Level } \\
statistic
\end{tabular} & & Value & SD & $t_{35}$ & $P<$ \\
\hline$F_{\mathrm{ST}}$ & Among subpopulations & 0.262 & 0.024 & 10.762 & 0.001 \\
$F_{\mathrm{NT}}$ & Among nests & 0.369 & 0.024 & 15.223 & 0.001 \\
$F_{\mathrm{IT}}$ & Among individuals & 0.273 & 0.026 & 10.370 & 0.001 \\
$F_{\mathrm{NS}}$ & Among nests within subpopulations & 0.145 & 0.007 & 20.811 & 0.001 \\
$F_{\mathrm{IS}}$ & Among individuals within subpopulations & 0.015 & 0.010 & 1.569 & $0.2 \mathrm{NS}$ \\
$F_{\mathrm{IN}}$ & Among individuals within nests within subpopulations & -0.151 & 0.009 & -16.370 & 0.001 \\
\hline
\end{tabular}

Standard errors are taken over nests using a jackknife algorithm, and 2-tailed significance levels are derived from $t$ tests against the null hypothesis that $F=0$.

lematic, and only the E. s. westwoodi subpopulations are included in the analyses below.

$F$ statistics considering only the Durango and Sinaloa subpopulations are shown in Table $3 . F_{\text {IN }}$ is significantly negative, indicating an excess of heterozygous larvae in nests, and this value remains consistently low across loci when analyzed separately. $F_{\text {IS }}$ is not significantly different from zero. However, it is appropriate here to compare $F_{\text {IS }}$ to $F_{\text {IN }}$ rather than zero, whereupon we find that $F_{\mathrm{IS}}$ is significantly higher $\left(t_{70}=74.1, P<0.0001\right)$, indicating an overall excess of homozygotes relative to the within-nest genotypic proportions. This suggests that there is likely to be spatial structure within the subpopulations, despite relatively continuous madrone habitat within our localities. This appears consistent with low female dispersal rates observed in mark-recapture experiments in natural populations (D.L.A.U., unpublished data).

Relatedness. Using only the Durango and Sinaloa subpopulations, where sufficient genetic variation was available, we found relatedness among nestmates within subpopulations to be $r_{\mathrm{NS}}=0.285$ \pm 0.012 . This is significantly lower than $r=0.5$ $\left(t_{35}=-17.41 ; P<0.0001\right)$, the relatedness expected between full siblings in an outbreeding population.

As a post-hoc test to determine whether the low relatedness within nests was attributable to nest coalescence, we repeated the analysis for the El Madroño subpopulation alone. Using data from all nests, we found $r_{\mathrm{NT}}=0.272 \pm 0.01$. We found relatedness of nestmates within trees was $r_{\mathrm{Ntr}}=$ $0.177 \pm 0.04$, significantly lower than the overall relatedness $\left(t_{35}=5.31, P<0.001\right)$. This suggests that nest coalescence is likely to play an important role in driving down average relatedness. Unfortunately, our sampling records do not permit us to look at relatedness within nests that were the sole occupants of trees.

\section{Discussion}

The genetic structure of Eucheira socialis is marked by limited polymorphism but strong differentiation among populations, with excess heterozygotes and moderate levels of relatedness among nestmates within subpopulations. These patterns are related to several aspects of both adult and larval natural history, discussed below.

Population Structure and Adult $E$. socialis Behavior. E. socialis are weak fliers. Females appear to mate once early in life and lay virtually all their eggs in a single clutch soon after mating (Underwood 1992). Adult dispersal is likely to be only several hundred meters at most (D.L.A.U., unpublished data), and under an isolation-by-distance model of population structure, numerous genetic neighborhoods would fit into each of the patches of madrone found in our study areas. Our nests in the Durango and Sinaloa sites were spread over $\approx 5$ ha within a madrone patch, and the difference between our $F_{\text {IN }}$ and $F_{\text {IS }}$ values (Table 3) qualitatively reflects the within-subpopulation differentiation that strong isolation by distance is expected to produce.

At larger geographic scales, gene flow among sampled $E$. socialis localities is probably restricted by 2 factors in addition to weak flight capabilities. First, madrone habitats are limited to elevations $>$ $1,800 \mathrm{~m}$, and they have been separated by extensive inhospitable regions since at least Pleistocene times. Second, there is strong karyotypic differentiation among northern and southern $E$. socialis populations (A.M.S. and S. R. Snow, unpublished data) that would probably act as postzygotic barriers should distant populations ever encounter one another naturally. Data are currently limited, but karyotypic differentiation appears correlated geographically with the minor morphological differences (A.M.S. and S. R. Snow, unpublished data) used to separate northern and southern populations into subspecies (Beutelspacher 1984, Díaz Batres and Boudinot 1986). The low gene flow $(M)$ estimate indicates that these $E$. socialis subpopulations have probably long been separated and are now evolving relatively independently of one another. Indeed, if they have been slowly diverging by genetic drift since achieving their current ranges, then drift and gene flow may not yet have equilibrated, and our calculated value of $M$ may be an overestimate. These subspecies may prove to be separate biological species upon closer inspection of intermediate localities. The high $F_{\mathrm{ST}}$ value refutes the hypothesis (Peigler 1993) that the current geographic range was achieved relatively recently 
by commerce among indigenous peoples, who reportedly used the nests for paper in pre-Columbian times and who continue to eat the pupae (Kevan and Bye 1991; unpublished observations).

In contrast to E. socialis, other studies of butterfly population genetic structure, conducted at comparable geographic scales, show very little differentiation among populations. In the Pieridae, Geiger and Shapiro (1992) and Porter and Geiger (1995) report low $F_{\mathrm{ST}}$ values despite high heterozygosities for Pieris napi (L.)-group taxa in California and Europe. This is associated with high dispersal rates of these butterflies (A. H. P., unpublished data). Similar work on Pieris rapae (L.) (Vawter and Brussard 1984) yields essentially the same picture, but associated in part with recent range expansion. Other butterfly species also have very low values of $F_{\mathrm{ST}}$, for example Limenitis weidemeyerii W. H. Edwards (Porter 1990), Euphydryas chalcedona (Doubleday) (McKechnie et al. 1975, Porter 1990), Coenonympha tullia (Müller) (Porter and Geiger 1988), and the migratory Danaus plexippus (L.) (Eanes and Koehn 1978) (all Nymphalidae). Euphydryas editha (Boisduval) has one of the highest values, at $F_{\mathrm{ST}}=$ 0.2 (McKechnie et al. 1975, Porter 1990). It is also interesting to note that the eastern tent caterpillar, a lasiocampid moth, has low levels of $F_{\mathrm{ST}}$ (Costa and Ross 1994) across eastern North America, similar to those of "normal" butterflies, rather than showing the high differentiation seen in $E$. socialis on a similar geographic scale. E. socialis has by far the highest $F_{\text {ST }}$ values reported in the Lepidoptera, even if only the 2 geographically close Durango and Sinaloa populations are considered. This is consistent with observations of limited dispersal capabilities in this species.

Eucheira socialis and Similarly Colonial Lepidoptera. The eastern tent caterpillar, Malacosoma americanum (F.), has a natural history superficially similar to that of $E$. socialis, with communal larval nests constructed by siblings from a single clutch (Costa and Ross 1993), and larval trails from the nest to patches of edible leaves (Fitzgerald and Willer 1983). Within-nest variation in M. americanum (Costa and Ross 1993) indicates that relatedness begins high, at $r_{\mathrm{NS}} \approx 0.5$ among early-instar nestmates, but nest coalescence and exchange among nests drives relatedness down to $r_{\mathrm{NS}}=0.38$ by the later instars. The saturniid moth Anisota senatoria J. E. Smith also lives communally, but does not construct nests. It shows reduced relatedness $\left(r_{\mathrm{NS}}=0.31\right)$ in late instar larval groups (Porter et al. 1997), and nest coalescence and exchange appears to be involved. We also have observed nest coalescence and exchange of individuals among nests in $E$. socialis. Judging from the comparison of relatedness among all nests $\left(r_{\mathrm{NT}}\right)$ to that among nests within trees $\left(r_{\mathrm{Ntr}}\right)$ at El Madroño, larval movement among nests appears to have a similarly strong homogenizing effect on population genetic structure. However, our follow-up analysis does not rule out the possibility that occasional multiple mating and egg dumping on clutches of other females also contributes in minor ways to reduced relatedness. $M$. americanum and other colonial Lepidoptera have 1:1 sex ratios, and in general share few of the remarkable traits characteristic of $E$. socialis.

Heterozygote Excesses. The significant heterozygote excesses $\left(F_{\text {IN }}\right)$ within nests at all 4 polymorphic loci are difficult to explain without invoking natural selection, although the mechanism(s) remains obscure. Field observations indicate that the nests are derived primarily from single clutches laid by females (Underwood 1992), and that females probably mate only once before ovipositing. Females do occasionally lay small numbers of eggs on the clutches of other females (D.L.A.U., unpublished data), and nests on a single tree appear to exchange members or coalesce, but these phenomena all lead to heterozygote deficiencies much in the way that pooling differentiated subpopulations yields homozygote excesses in the total population.

Limited Polymorphism. E. socialis, especially the subspecies E. s. socialis, has among the lowest levels of polymorphism yet reported in the Lepidoptera; only Yponomeuta rorellus Hübner (Yponomeutidae) has values in this range $(0.0 \leq H \leq$ 0.015 [Menken 1987]).

\section{Acknowledgments}

We are indebted to Arturo Franco-Gaona, Armando Luis, Dave Whitacre, and Beth Jakob for collecting assistance; L. Frauchiger and V. Siegfried for help with gels; F. Ayala and A. Scholl for graciously providing space in their laboratories; and Beth Jakob, Steve Vessey, Carlos Cordero, Carl Schaefer, and 2 anonymous reviewers for fruitful discussions and comments on previous drafts of the manuscript. We thank Harry Kaya for examining multiple larval samples for potential pathogens and the late S. Richard Snow for help with the cytology. U. S. Animal and Plant Health Inspection Service (APHIS) permit numbers were 57-24-85 and 57-35-92 (926862). This study was supported in part by grants from the University of California's UC Mexus program to A.M.S. and J.L.-B., National Geographic Society $(3700-87)$ to A.M.S., and DGAPA-UNAM (IN-200394) to J.L.-B.

\section{References Cited}

Beutelspacher, C. R. 1984. Una nueva subespecie du Eucheira socialis Westwood (Lepidoptera: Pieridae) de México. An. Inst. Biol. Univ. Nac. Auton. Mex., Ser. Zool. 54: 111-118.

Chesser, R. K., O. E. Rhodes, Jr., D. W. Sugg, and A. Schnabel. 1993. Effective sizes for subdivided populations. Genetics 135: 1221-1232.

Cockerham, C. C. 1969. Variance of gene frequencies. Evolution 23: 72-84.

1973. Analysis of gene frequencies. Genetics 74: 679700 .

Cockerham, C. C., and B. S. Weir. 1993. Estimation of gene flow from F-statistics. Evolution 47: 855-863.

Costa, J. T. III, and K. G. Ross. 1993. Seasonal decline in intracolony genetic relatedness in eastern tent 
caterpillars: implications for social evolution. Behav. Ecol. Sociobiol. 32: 47-54.

1994. Hierarchical genetic structure and gene flow in macrogeographic populations of the eastern tent caterpillar (Malacosoma americanum). Evolution 48: 1158-1167.

Díaz Batres, M. E., and J. Boudinot. 1986. Eucheira socialis westwoodi Beutelspacher, 1984: contribution à sa systématique. Rev. Fr. Entomol. 3: 135-143.

Eanes, W. F., and R. K. Koehn. 1978. An analysis of genetic structure in the Monarch butterfly, Danaus plexippus L. Evolution 32: 784-797.

Fitzgerald, T. D., and D. E. Willer. 1983. Tent-building behavior of the eastern tent caterpillar Malacosoma americanum (Lepidoptera: Lasiocampidae). J. Kans. Entomol. Soc. 56: 20-31.

Frank, S. A. 1987. Demography and sex ratio in social spiders. Evolution 41: 1267-1281.

Geiger, H. J. 1981. Enzyme electrophoretic studies on the genetic relationships of pierid butterflies. I. European taxa. J. Res. Lepid. 19: 181-195.

Geiger, H. J., and A. Scholl. 1985. Systematics and evolution of holarctic Pierinae (Lepidoptera): an enzyme electrophoretic approach. Experientia 41: 24 29.

Geiger, H. J., and A. M. Shapiro. 1986. Electrophoretic evidence for speciation within the nominal species Anthocharis sara Lucas (Pieridae). J. Res. Lepid. 25: $15-24$

1992. Genetics, systematics and evolution of holarctic Pieris napi species group populations (Lepidoptera, Pieridae). Z. Zool. Syst. Evolutionforsch. 30: 100-122.

Grafen, A. 1985. A geometric view of relatedness. Oxf. Surv. Evol. Bio. 2: 28-89.

Hamilton, W. D. 1964. The genetical evolution of social behavior, I. J. Theor. Biol. 7: 1-16.

1967. Extraordinary sex ratios. Science (Wash. D.C.) 156: $477-488$.

1971. Selection of selfish and altruistic behavior in some extreme models, pp. 57-91. In J. F. Eisenberg and W. S. Dillon [eds.], Man and beast: comparative social behavior. Smithsonian Institution Press, Washington, DC.

Hoffmann, C. C. 1911. Humboldts Nachrichten über die in Mexico einheimischen seidenspinnenden Raupen, unter spezeiller Bearbeitung des von ihm erwähnten Madroño: Falters Eucheira socialis Westw. Fauna Exotica 12: 1-33.

Kevan, P. G., and R. A. Bye. 1991. The natural history, sociobiology, and ethnobiology of Eucheira socialis Westwood (Lepidoptera: Pieridae), a unique and little known butterfly from Mexico. Entomologist 110: 146-165.

Malécot, G. 1969. The mathematics of heredity, D. M. Yermanos [translator]. Freeman, San Francisco.

MeKechnie, S. W., P. R. Ehrlich, and R. R. White. 1975. Population genetics of Euphydryas butterflies. I. Genetic variation and the neutrality hypothesis. Genetics 81: 571-594.

Menken, S. B. J. 1987. Is the extremely low heterozygosity level in Yponomeuta rorellus caused by bottlenecks? Evolution 41: 630-637.

Michod, R. E. 1993. Inbreeding and the evolution of social behavior, pp. 74-96. In N. W. Thornhill [ed.], The natural history of inbreeding and outbreeding: theoretical and empirical perspectives. University of Chicago Press, Chicago.
Nei, M. 1973. Analysis of gene diversity in subdivided populations. Proc. Natl. Acad. Sci. U.S.A. 70: 33213323.

Pamilo, P. 1984. Genotypic correlation and regression in social groups: multiple alleles, multiple loci and subdivided populations. Genetics 107: 307-320.

1989. Estimating relatedness in social groups. Trends Ecol. Evol. 4: 353-355.

Peigler, R. S. 1993. Wild silkmoths of the world. Bull. Entomol. Soc. Am. 39: 151-161.

Porter, A. H. 1990. Testing nominal species boundaries using gene flow statistics: the taxonomy of two hybridizing admiral butterfies (Limenitis: Nymphalidae). Syst. Zool. 39: 131-148.

Porter, A. H., and H. J. Geiger. 1988. Genetic and phenotypic population structure of the Coenonympha tullia complex (Lepidoptera: Nymphalidae: Satyrinae) in California: no evidence for species boundaries. Can. J. Zool. 66: 2751-2765.

1995. Limitations to the inference of gene flow at regional geographic scales-an example from the Pieris napi group (Lepidoptera: Pieridae) in Europe. Biol. J. Linn. Soc. 54: 329-348.

Porter, A. H., S. J. Cadaret, S. A. Johnson, H. Mizohata, A. I. Benedetter, C. L. Bester, J. L. Borash, S. D. Kelly, G. S. Buehner, and M. L. Sherman. 1997. Relatedness and gregariousness in the orange-striped oakworm, Anisota senatoria (Lepidoptera: Saturniidae). J. Lepid. Soc. 51: (in press).

Queller, D. C., and K. F. Goodnight. 1989. Estimating relatedness using genetic markers. Evolution 43 : 258-275.

Slatkin, M. 1987. Gene flow and geographic structure of natural populations. Science (Wash. D.C.) 236: 787-792.

Thornhill, N. W. 1993. The natural history of inbreeding and outbreeding: theoretical and empirical perspectives. University of Chicago Press, Chicago.

Underwood, D. 1992. Factors influencing oviposition behavior in the Mexican pierid butterfly, Eucheira socialis, on its host plant, Arbutus xalapensis (Ericaceae). Ph.D. dissertation, University of California, Davis.

1994. Intraspecific variability in host plant quality and ovipositional preferences in Eucheira socialis (Pieridae: Lepidoptera). Ecol. Entomol. 19: 245-256.

Vawter, A. T., and P. F. Brussard. 1984. Allozyme variation in a colonizing species: the cabbage butterfly Pieris rapae (Pieridae). J. Res. Lepid. 22: 204-216.

von Humboldt, A. 1811. Essai politique sur le royaume de la Nouvelle Espagne, vol. 4. F. Schoell, Paris.

Weir, B. S. 1990. Genetic data analysis. Sinauer, Sınderland, MA.

Weir, B. S., and C. C. Cockerham. 1984. Estimating $F$-statistics for the analysis of population structure. Evolution 38: 1358-1370.

Westwood, J. O. 1834. Description of the nest of a gregarious butterfly from México. Trans. R. Entomol. Soc. Lond. 1: 38-44.

Wright, S. 1951. The genetical structure of populations. Ann. Eugen. 15: 323-354.

1978. Evolution and the genetics of populations, vol. 4. Variability within and among natural populations. University of Chicago Press, Chicago.

Received for publication 9 July 1996; accepted 24 September 1996. 